\title{
Sciences
}

Vol. 06, No. 02, pp. 86-102, June 2013

\section{DESIGN AND MANUFACTURING OF A HYDROSTATIC EXTRUSION APPARATUS FOR COMPOUND CYLINDERS FROM AL AND MG}

\author{
Mohsen J. Joaij ${ }^{1}$, Moneer H. Tlafeh ${ }^{2}$, Abdullah D. Assi ${ }^{3}$, Esam T. Abdullah ${ }^{4}$ \\ ${ }^{1}$ Engineering College, Nahreen University, ${ }^{2,4}$ Technical College, Baghdad University, \\ ${ }^{3}$ Technical Instiute, Baghdad \\ (Received:11/12/2011; Accepted:19/9/2012)
}

\begin{abstract}
The purpose of this research is to design and construct an experimental hydrostatic extrusion apparatus which has a maximum working pressure of $500 \mathrm{bar}$, and to reduce the cost of this extrusion apparatus. The high-pressure extrusion container has been designed with hydraulic cylinders which is cheap and readily available. Different materials and designs for high-pressure seals were tested and analyzed for the best combination performance. Problems in the extrusion processes using this device were analyzed and solved, which increased the reliability of the device. The results of extrusion experiments have established that this device is practicable.
\end{abstract}

Keywords: Design, hydrostatic, pressure, analyzed.

\section{1-INTRODUCTION}

Progress of technology has caused the development of new materials to fulfill new engineering demands, e.g., new alloys. These new materials are often difficult to produce. Among the new processes that were developed in recent years to produce these new materials, hydrostatic extrusion appears to have the greatest potential. The difference between the conventional extrusion and hydrostatic extrusion is that the latter uses fluid (high-pressure fluid) as pressure-transmitting medium instead of direct contact. During the extrusion, this fluid transmits a hydrostatic pressure to the billet, which can largely increase the ductility of the extrusion materials. This fluid also acts as a lubricant between the die and billet (Compound Cylinders from $\mathrm{Al}$ and $\mathrm{Mg}$ ) and results in a near frictionless operation. Therefore the process is capable of extruding many difficult-to-deform materials. 
The hydrostatic extrusion machine can be divided into seven parts (Fig.1,2\&3):

(1) a high-pressure extrusion container (pressure medium),

(2) a high-pressure seal ('O' Ring seal and copper seal),

(3) a high-pressure source(press) and a high-pressure plunger(punch),,

(4) hydraulic endures a high-temperature,

(5) a pressure intensifier device and ram,

(6) a main pressure gauge ,and

(7) die and billet or bolt with sleeve and core.

The cost of a typical hydrostatic extrusion device is very high compared to that of a traditional device, therefore, to design a practical and commercially viable device has become an important engineering topic.

The idea of hydrostatic extrusion was first established by Robertson ${ }^{(1)}$, but the method was first experimented by Bridgman ${ }^{(2)}$. Later research and development work was carried out by Pugh ${ }^{(3)}$ and his colleagues. They developed the back pressure system in $1964^{(4)}$, that can prevent the cracking of brittle material in simple hydrostatic extrusion. Following this, further research and experimentation was done at High Pressure Laboratory of the Academy Sciences of the USSR, as well as in the USA, and Japan. The disadvantage of simple hydrostatic extrusion is that the extrusion speed is uncontrollable. Sakai and Horita ${ }^{(5)}$ presented the way of "augmented hydrostatic extrusion" to overcome this problem. With this method, when the fluid pressure is insufficient to extrude the billet, an additional force is applied to the rear end of the billet by a solid ram.

The extrusion speed can thus be well controlled .However; the length of the billet is then limited by buckling under the axial compressive force of the ram.

When Bridgman experimented with hydrostatic extrusion, he observed a severe fluctuation in the pressure, which was related to the "stick and slip phenomenon". This happened because the fluid is compressible under the high pressure. When extrusion begins, there is a sudden drop in pressure and the extrusion process then stops until the pressure builds up again. Zhao and Liao ${ }^{(6)}$ introduced a method to overcome the "stick and slip phenomenon". He built a hydrostatic extrusion machine in which the volume of oil and the speed of the ram can be matched to prevent the occurrence of the phenomenon. Later, Witkin and Lavernia ${ }^{(7)}$ designed a cross-bore arrangement hydrostatic extrusion machine which had a maximum design pressure of 500 bar. The advantage of this arrangement is that the rams never need to be withdrawn from the ram chamber, which reduces the machine cycle time. These developments simplified the hydrostatic extrusion machine and decreased its cost. 
Today, the usage of hydrostatic extrusion is still limited to special applications such as golden-wire making for the semiconductor industry. The main cause obstructing the development is the cost of the device. Therefore, the topics of this research are not only to design and construct a hydrostatic extrusion device but also to solve problems during its operation and to simplify the equipment by using commercially available materials.

One of the most important components of this apparatus is the container that is required to contain the die, high pressure fluid and billet. According to Lame's equation for a thick wall cylinder ${ }^{(8)}$. The properties that need to be considered include surface finishing accuracy, material yielding and cracking criteria, seal design and elastic bending problems. Two main processes in the design of this hydrostatic extrusion container are explained in the following sections.

\section{THE DESIGN OF A HYDROSTATIC EXTRUSION APPARATUS}

The Design and manufacturing of all steps are processing in Technical Collage /Baghdad workshop and labs.

\subsection{High-pressure extrusion container}

One of the most important components of this apparatus is the container that is required to contain the die, high pressure fluid and billet. According to Lame's equation for a thick wall cylinder ${ }^{(8)}$, the maximum stress at the internal wall of cylinder will reach 500 bar when an internal pressure of 350 bar is applied. Therefore, a hydraulic cylinder container fig-4 was adopted in this design as the pressure container, and the material chosen is SKD61 tool steel, which is relatively cheap and commercially available. The properties that need to be considered include surface finishing accuracy, material yielding and cracking criteria, seal design and elastic bending problems.

\subsection{High-pressure fluid}

The high-pressure fluid (hydraulic) which has been taken from Al-Dura Refinery endures high temperatures about $300 \mathrm{C}^{\mathrm{o}}$. The fluid surrounding the billet has two functions, i.e. to transmit pressure and to lubricate the interface between the billet and the die. Under high pressure, the properties required for the fluid include compressibility, good lubrication and stability. 


\subsection{The damage of high-pressure seal}

The design of the high-pressure seal was first introduced by Park ${ }^{(10)}$. It consists of an "O" ring backed by a metal backup-ring. When the pressure increases the friction will also increase between the backup-ring and the container and thus results in an additional torsion moment. Furuno ${ }^{(11)}$ developed a ladder-shaped cross-section ring to overcome this problem. Also the seal used for this hydrostatic extrusion apparatus from copper ring to endure a hightemperature reach to $600 \mathrm{C}$ and it can be used up to a pressure of 500 bar.

After a few tests, the metal miter ring showed plastic deformation. The bottom of miter ring became very sharp and was responsible for the scratches mentioned above. The most probable cause for this problem is the moving seal design that had been used. With this original design, the miter ring had been moving with the plunger and was subjected to plastic deformation because of the high pressure and relative friction with respect to the container surface.

\section{HIGH-PRESSURE SOURCE}

The high pressure of this experimental hydrostatic extrusion apparatus comes from the compressed fluid in a pressure container (Fig.5). This cylindrical pressure container has an inner bore, $60 \mathrm{~mm}$ in diameter, fitted to a plunger. When a universal-testing machine with maximum capacity of 80 ton is used to compress the fluid in the container through this plunger, a magnified fluid pressure as high as 500 bar will be obtained in the pressure container.

\section{THE HYDROSTATIC EXTRUSION EXPERIMENTS}

Hydrostatic extrusion experiments were conducted using the above apparatus to test its practicability as well as to observe the properties of materials after high-pressure extrusion. The processes of the experiments are discussed in the following sections.

\subsection{Extrusion die}

The design of a hydrostatic extrusion die is more complicated than that of a traditional die. Special concerns include the high-pressure sealing and high material strength. In this experiment the inner diameter of the extrusion container is $45,40,35 \mathrm{~mm}$, which limits the size of the billet. Therefore, the upper section of die was set to 45,40 and $35 \mathrm{~mm}$ in outer diameter with a ladder-shape.. For the present specific extrusion ratio, the exit diameter of die was set 
to $60 \mathrm{~mm}$ and the angle of extrusion die (best) is $45^{\circ}$ under Aluminum condition. The material used for the extrusion die (Fig. 5) isSKD61 that had been heat-treated to a hardness of HRC53.

\subsection{Extrusion billet (Compound Cylinders from $\mathrm{Al}$ and $\mathrm{Mg}$ )}

The aluminum alloy of AlMgSil (DIN 1725-1) which is used in the electrical industry is used as a billet. The chemical composition of this material is illustrated in table (1).

Magnesium $(\mathrm{Mg})$ relative density $1738 \mathrm{Kg} / \mathrm{m} 3(1.738 \mathrm{Kg} / \mathrm{dm} 3)$ and melting point 651 $\mathrm{C}^{\mathrm{o}}$, boiling point $1107 \mathrm{C}^{\mathrm{o}}$, crystal structure: close packed hexagonal $(\mathrm{a}=3.2030 \mathrm{c}=5.2002)^{(12)}$ ,Magnesium criterion is (AZ63A) from SAE AMS4420 ${ }^{(13,15)}$.

The billets designed for hydrostatic extrusion experiment thad the shape of a rod. The front ends of the billets were turned to a cone shape of $45^{\circ}$ and were polished in order to fit into the die entrance tightly without any leakage of fluid. Two types of billets were tested to explore the effects of hydrostatic extrusion. The first type of billets was made from hollow rod of aluminum (Al) and solid rod (core) of Magnesium $(\mathrm{Mg})$.

\section{4-3. Preparation of samples surface}

\section{1- Grinding}

Silicon carbide papers are used to grind the specimens, for different size $(180,240$, $320,400,500,600,800,1000$ and 1200) to modify of specimens surface. Then using water in order to cooling and ensuring no change of mechanical properties during grinding process.

\section{2- Polishing}

DP-COLTHES papers (200mm Diameter) are used with polishing solution type(A12O3) for light and ductile metals such as $\mathrm{Al}$ and $\mathrm{Mg}{ }^{(13)}$, then rotate the specimen by $60^{\circ}$ about all direction in each polishing stage in order to obtain mirror surface.

\section{3- Etchant}

The etchant solutions are used to complete the etchant treatment, all these procedure in Ministry of science and Technology/Department of chemical and physical research. Additionally to use Microscope type NIKON ECLIPSE ME600 and Micro camera type NIKON etchant microstructure and grain size. 


\subsection{Hardness Testing}

The two hardness are tested, Vickers and Brinal before and after a hydrostatic extrusion for two metals. These testing in Ministry of science and Technology /Department of chemical and physical research, and all results are showing in table(7)

Where:

HV : Vickers Hardness and HB : Brinal Hardness

$\mathrm{HV}=18544 * 10-4 * \mathrm{P} 1 / \mathrm{d} 12$

$\mathrm{P} 1=$ Force $(\mathrm{N})=0.49 \mathrm{~N}$

$\mathrm{d} 1=$ length of the long diagonal of the indentation $(\mathrm{mm})$

$$
\mathrm{HB}=\frac{\mathrm{p}}{\pi^{*} 0.5 \mathrm{D}\left(\mathrm{D}-\sqrt{D^{2}-d^{2}}\right)}
$$

$\mathrm{P}=$ load $=62.5 \mathrm{~N}$

$\mathrm{D}=$ Diameter of Ball $=2.5 \mathrm{~mm}$

$\mathrm{d}=$ diameter of adenter in surface or area $(\mathrm{mm})$.

Now, Vickers hardness testing before and after a hydrostatic extrusion for two metals Aluminum (AlMgSi1) and Magnesium (AZ63A)

\section{RESULTS AND DISCUSSION}

This section summarizes and discusses the results of the hydrostatic extrusion on three types of billets as show in the table (8).

When the hydrostatic extrusion device was design and manufacturing and prepare the Al and $\mathrm{Mg}$ specimens as compound cylinders, the hydrostatic extrusion system including specimen and die (diameter $45 \mathrm{~mm}$ ) are putting in furnace as shown in fig.(g) then increasing the temperature to $300 \mathrm{C}^{\circ}$ then it is putted in press as shown in fig.(5).

At the pressure equal to 200 bar, the press is stopped, as shown in fig.(10). All these treatment are repeated for another size of die $40 \mathrm{~mm}$ and $35 \mathrm{~mm}$ but the value of pressure for type $40 \mathrm{~mm}$ is 250 bar ...etc. When the diameter of die is decreased the length of product is increased.

\subsection{Microstructure and grain size}

In extrusion experiment 1, a wide interface (10 to $50 \mu \mathrm{m})$ with ramified cracks and eutectic structures as observed by a metallographic analysis of the compound of the alloyed materials, Fig. 12(g,h) ${ }^{(15)}$. By means of a micro hardness test, high values of hardness (until $300 \mathrm{HV}$ 0.05) in the region of the interface were proved. These analyses were realized by 
(Ministry of science and Technology /Department of chemical and physical research ). At the interface of the unalloyed basic materials, only a few hard and damaged sections were found. Furthermore, it was demonstrated that the interface is melting at temperatures of $650{ }^{\circ} \mathrm{C}$. This is one of the melting temperatures of the eutectic mixtures at the $\mathrm{Mg}$-Al phase diagram. This allows the conclusion that the interface was produced by a melting process during the coextrusion because of high temperatures and subsequent cooling.

For extrusion experiment 2, the temperature of bolt and die was reduced to $300{ }^{\circ} \mathrm{C}$ (alloyed material)and $350{ }^{\circ} \mathrm{C}$ (unalloyed material). A metallographic analysis shows that eutectic mixtures do not occur any longer. Thus, it seems that the temperature of $650{ }^{\circ} \mathrm{C}$ was not reached. The microstructure of the transition area shows now a narrow interface without melted structures. In the case of the co-extruded alloyed materials (Al-Mg Compound Cylinders), a partially bonded compound occurs ${ }^{(16)}$. The two metals are bonded only on one side of the circumference of the interface. The unbounded parts in the middle of the coextrusion rod take approximately 30 to $40 \%$ of the circumference, additionally to the metallographic investigations.

\section{CONCLUSIONS}

In this research, an experimental hydrostatic extrusion apparatus was designed and Manufactured, built and modified with emphases on both simplicity of structure and low cost with commercially available materials. Three types of billets were extruded using this apparatus to verify its practicability. Satisfactory testing results were obtained together with some information on the material behavior under hydrostatic pressure. While further investigations on the effects of hydrostatic extrusion parameters are going to be carried out, several conclusions may be summarized at this stage.

1. The high-pressure container with cylinders design has been proven to sustain a maximum working pressure of 500 bar safely.

2. Although the design of copper seals is more simple than that of rubber seals, the rubber seal still cannot sustain high temperature repeatedly. Therefore, copper seals are suggested for high-temperature and pressure hydrostatic extrusion apparatus.

3. For precisely controlling the magnitude of the hydrostatic pressure at which the billets are extruded, a backpressure device is needed.

4. Hydrostatic extrusion was utilized as a final compaction process for the cryomilled and subsequently hipped Al-Mg. Mechanical behavior was examined by tensile 
experiment for as-hipped and as-extruded specimens. Strength and ductility were increased after Hydrostatic extrusion, which offers the possibility of this process as a final consolidation process.

\section{REFERENCES}

1. J. Robertson, Method of and apparatus for forming metal articles, British Patent No. 19356 (October 14, 1893); US Patent No. 524504 (August 14, 1894).

2. P.W. Bridgman, Studies in Large Plastic Flow and Fracture, McGraw-Hill, New York, 1952 .

3. H.L1.D. Pugh, D. Gunn, in: International Symposium on the Physics and Chemistry of High Pressures, Society of Chemical Industry, London, 1963, pp. 157士159.

4. H.L1.D. Pugh, A.H. Low, The hydrostatic extrusion of difficult metals, J. Inst. Met. 93 $(1964 \pm 1965)$.

5. G. Sakai, Z. Horita, T.G. Langdon, Grain refinement and super plasticity in an aluminum alloy processed by high-pressure torsion, Mater. Sci. Eng. A 393(2005)344.

6. Y.H. Zhao, X.Z. Liao, Y.T. Zhu ,influence of stacking fault energy on nanostructure formation under high pressure torsion, Mater .Sci. Eng. A 410/411(2005)188.

7. D.B. Witkin, E.J. Lavernia, Synthesis and mechanical behavior of nano structured materials via cryomilled Prog. Mater. Sci. 51(2006) 1.

8. S. Timoshenko, "Strength of Materials", Part II, Van Nostrand, Princeton, NJ, 1930.

9. B.Q. Han, E.J. Lavernia , High-temperatuer behavior of a cryomilled ultrafine-grained Al-7.5 \% Mg alloy, Mater.Sci.Eng. A 410/411(2005)417.

10. Y.S. Park, K.H. Chung, Micro structural investigation of nano crystalline bulk Al-Mg alloy fabricated by cryomilling and extrusion, Mater. Sci. Eng. A 374(2004)211.

11. K. Furuno, H. Akamatsu, T.G. Langdon, Microstructural development in equalchannel angular pressing using a 60[deg] die,Acta Mater. 52(2004)2497.

12. pekguleryuz, Mihriban Ozden; et al Magnesium-based casting alloys having improving elevated temperature performance, oxidation-resistant magnesium alloy melts, Magnesium-based alloy castings prepared there from and method for preparing same, US Patent Application 20020104593 August 8,2002.

13. Metals Handbook ninth Edition Volume-9 metallography and microstructures, 1985,Al in page 352 ,Table-1 ,No.4 \&Mg in page 426, Table-1,No.-1. 
14. Lefebvre; Michel (Pierrefonds, CA); Magnesium-based casting alloys having improved elevated temperature properties United States Patent 6,342,180 January 29,2002 .

15. Lehmann, T.: Residual Stress Analysis of $\mathrm{Al} / \mathrm{Mg}$ Compounds Using the Hole Drilling Method and Strain Gage Rosettes (in German), Reports in Applied Measurements (2010), online published at www.hbm.com.

16. Kittner, K., Awiszus, $\quad$ B.: $\quad$ Examinations and Simulation of the Interface of an Aluminum- Magnesium Compound. Proc. 9th International Conference on Technology of Plasticity (2008), 258-259.

Table (1): The chemical composition for the aluminum alloy of AlMgSil (DIN 1725-1).

\begin{tabular}{|c|c|c|c|c|c|c|c|c|}
\hline Element & $\mathrm{Si}$ & $\mathrm{Fe}$ & $\mathrm{Cu}$ & $\mathrm{Mn}$ & $\mathrm{Mg}$ & $\mathrm{Zn}$ & $\mathrm{V}$ & $\mathbf{A L}$ \\
\hline$\%$ & 1.12 & 0.3 & 0.3 & 0.424 & 0.923 & 0.026 & 0.003 & $\mathbf{9 6 . 9}$ \\
\hline
\end{tabular}

Table (2): The mechanical properties of the aluminum alloy of AlMgSi1 (DIN 1725-1).

\begin{tabular}{|c|c|c|c|c|c|c|c|c|}
\hline $\begin{array}{c}\sigma \mathrm{u} \\
(\mathrm{MPa})\end{array}$ & $\begin{array}{c}\sigma \mathrm{y} \\
(\mathrm{MPa})\end{array}$ & $\begin{array}{c}\text { Elongation } \\
\mathrm{mm}\end{array}$ & $\begin{array}{c}\mathrm{E} \\
(\mathrm{Gpa})\end{array}$ & $\begin{array}{c}\text { Poission's } \\
\text { ratio }\end{array}$ & $\mathrm{HV}$ & $\mathrm{HB}$ & $\begin{array}{c}\text { density } \\
\left(\mathrm{Kg} / \mathrm{m}^{3}\right)\end{array}$ & $\begin{array}{c}\text { Melting } \\
\text { point } \\
\mathrm{C}^{\mathrm{o}}\end{array}$ \\
\hline 310 & 260 & 10 & 70 & 0.3 & 61 & 106 & 2700 & 685 \\
\hline
\end{tabular}

Table (3): the chemical composition for the Magnesium alloy of AZ63A from SAE AMS4420.

\begin{tabular}{|c|c|c|c|c|c|c|c|c|}
\hline Element & $\mathrm{Al}$ & $\mathrm{Cu}$ & $\mathrm{Mn}$ & $\mathrm{Ni}$ & $\mathrm{Si}$ & $\mathrm{Zn}$ & Total others & $\mathrm{Mg}$ \\
\hline$\%$ & 6 & 0.1 & 0.15 & 0.01 & 0.3 & 3.04 & 0.4 & $\mathbf{9 0}$ \\
\hline
\end{tabular}

Table (4): the mechanical properties of the Magnesium alloy of AZ63A from SAE AMS4420.

\begin{tabular}{|c|c|c|c|c|c|c|c|c|}
\hline $\begin{array}{c}\sigma \mathrm{u} \\
(\mathrm{Mpa})\end{array}$ & $\begin{array}{c}\sigma \mathrm{y} \\
(\mathrm{Mpa})\end{array}$ & $\begin{array}{c}\text { Elongation } \\
\mathrm{mm}\end{array}$ & $\begin{array}{c}\mathrm{E} \\
(\mathrm{Gpa})\end{array}$ & $\begin{array}{c}\text { Poission's } \\
\text { ratio }\end{array}$ & $\mathrm{HV}$ & $\mathrm{HB}$ & $\begin{array}{c}\text { density } \\
\left(\mathrm{Kg} / \mathrm{m}^{3}\right)\end{array}$ & $\begin{array}{c}\text { Melting } \\
\text { point } \mathrm{C}^{\mathrm{o}}\end{array}$ \\
\hline 151 & 76 & 4 & 45 & 0.33 & 33 & 75 & 1738 & 650 \\
\hline
\end{tabular}


DESIGN AND MANUFACTURING OF A HYDROSTATIC EXTRUSION APPARATUS FOR

COMPOUND CYLINDERS FROM AL AND MG

Table(5)

\begin{tabular}{|c|c|c|c|c|}
\hline No. & $\begin{array}{c}\text { Sample before } \\
\text { HV (Al) }\end{array}$ & $\begin{array}{c}\text { Sample after } \\
\text { HV(Al) }\end{array}$ & $\begin{array}{c}\text { Sample before } \\
\text { HV(mg) }\end{array}$ & $\begin{array}{c}\text { Sample after } \\
\text { HV(Mg) }\end{array}$ \\
\hline 1 & 30.5 & 38.6 & 53 & 56.5 \\
\hline 2 & 32.2 & 39.2 & 55 & 63.1 \\
\hline 3 & 35.5 & 39.5 & 68.3 & 71.3 \\
\hline 4 & 35.8 & 43.7 & 77.6 & 108 \\
\hline 5 & 36.3 & 45.4 & 82.8 & 456.2 \\
\hline 6 & 37.1 & 47.0 & 397.1 & \\
\hline sum & 207.4 & 253.4 & 66.183 & \\
\hline mean & 34.56 & 42.23 & & 58.9 \\
\hline
\end{tabular}

Table(6): Material and composition which use etchant ${ }^{(13,15)}$.

\begin{tabular}{|c|c|c|c|}
\hline material & Etchant & composition & Time(sec) \\
\hline $\begin{array}{c}\text { Aluminum } \\
(\text { AlMgSil) }\end{array}$ & $\begin{array}{c}\text { poulton's } \\
\text { reagent }\end{array}$ & $\begin{array}{c}12 \mathrm{~mL} \text { from } \mathrm{HCl}(\mathrm{conc}), 6 \mathrm{~mL} \text { from } \mathrm{HNO} 3 \text { (conc), } \\
1 \mathrm{~mL} \text { from } \mathrm{HF}(48 \%), 1 \mathrm{ML} \text { from H2O }\end{array}$ & 30 \\
\hline $\begin{array}{c}\text { Magnesium } \\
(\mathrm{AZ63 \textrm {A }})\end{array}$ & Nital & $\begin{array}{r}1 \text { to } 5 \mathrm{~mL} \text { from } \mathrm{HNO} \text { (conc).100mL from } \\
\text { ethanol }(95 \%) \text { or methanol }(95 \%)\end{array}$ & 20 \\
\hline
\end{tabular}

Table(7): Vickers and Brinal Hardness testing.

\begin{tabular}{|c|c|c|c|}
\hline $\begin{array}{c}\text { Sample } \\
\text { No. }\end{array}$ & Element & $\begin{array}{c}\text { HV } \\
\text { Load }=0.49 \mathrm{~N}\end{array}$ & $\begin{array}{c}\text { HB } \\
\text { Load }=62.5 \mathrm{~N}\end{array}$ \\
\hline 1 & $\mathrm{Al}$ & 61 & 106 \\
\hline 2 & $\mathrm{Mg}$ & 39 & 75 \\
\hline
\end{tabular}

Table (8): Examples of the hydrostatic extrusion tests.

\begin{tabular}{|c|c|c|c|c|}
\hline No. & Material & $\begin{array}{c}\mathrm{D}_{\text {sleeve }} / \mathrm{D}_{\text {core }} \\
{[\mathrm{mm}]}\end{array}$ & $\begin{array}{c}\mathrm{T}_{\text {bolt }} / \mathrm{T}_{\text {die }} \\
{\left[{ }^{\circ} \mathrm{C}\right]}\end{array}$ & $\begin{array}{c}\varphi \\
{[\mathrm{deg} .]}\end{array}$ \\
\hline 1 & Al-Mg & $50 / 30 \rightarrow 45 / 28$ & $300 / 300$ & 45 \\
\hline 2 & Al-Mg & $50 / 30 \rightarrow 40 / 24$ & $300 / 300$ & 45 \\
\hline 3 & Al-Mg & $50 / 30 \rightarrow 35 / 22$ & $300 / 300$ & 45 \\
\hline
\end{tabular}




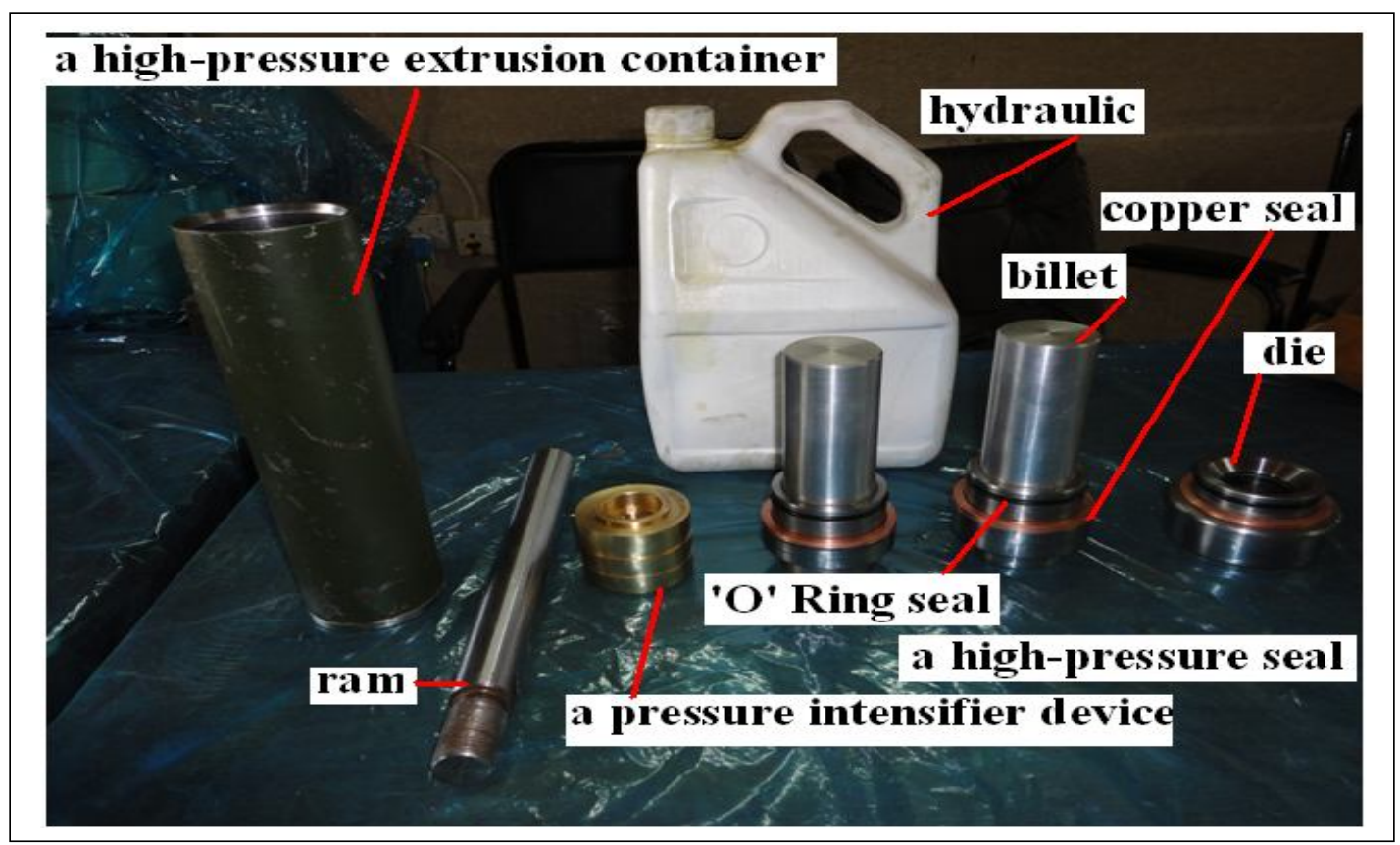

Fig.(1): The system parts.

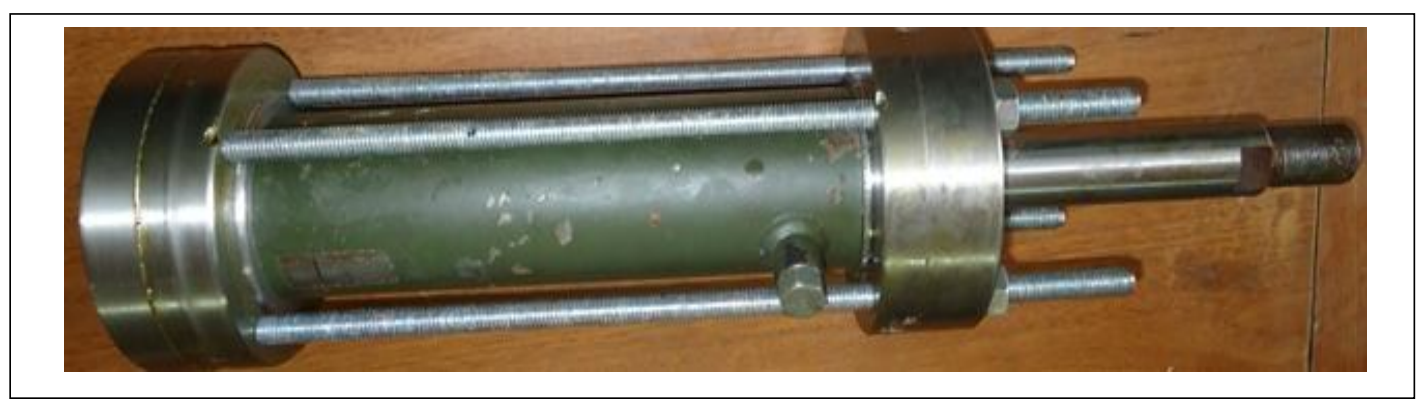

Fig.(2): The hydrostatic extrusion apparatus.

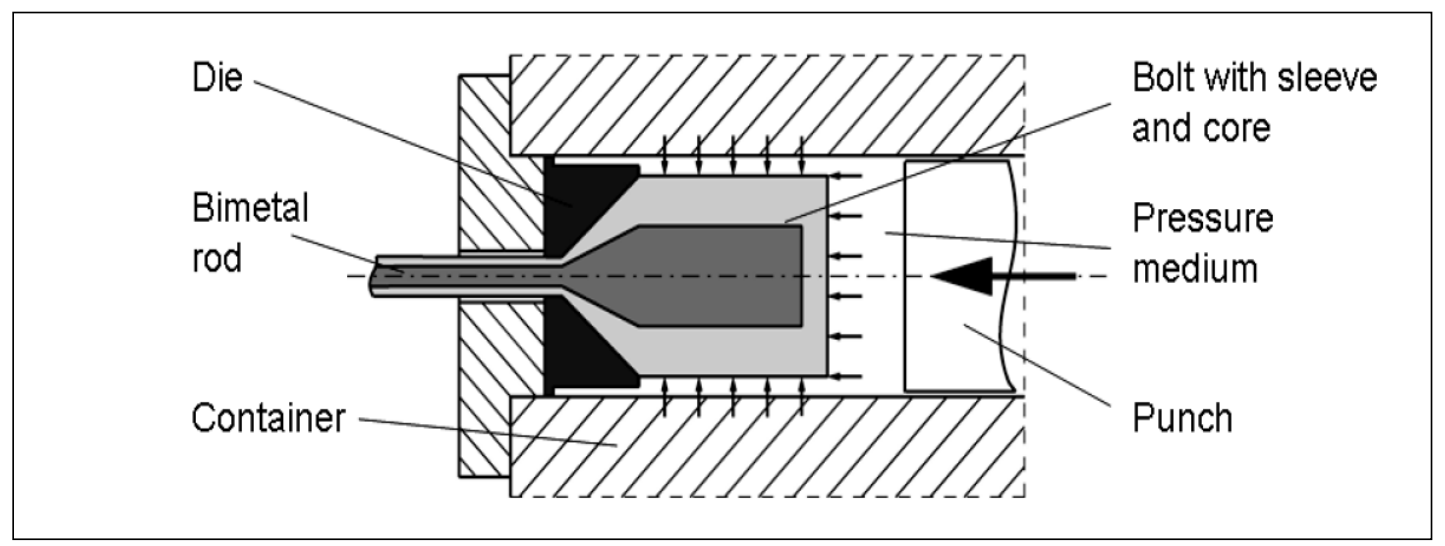

Fig.(3): Principle of the hydrostatic extrusion process. 
DESIGN AND MANUFACTURING OF A HYDROSTATIC EXTRUSION APPARATUS FOR COMPOUND CYLINDERS FROM AL AND MG
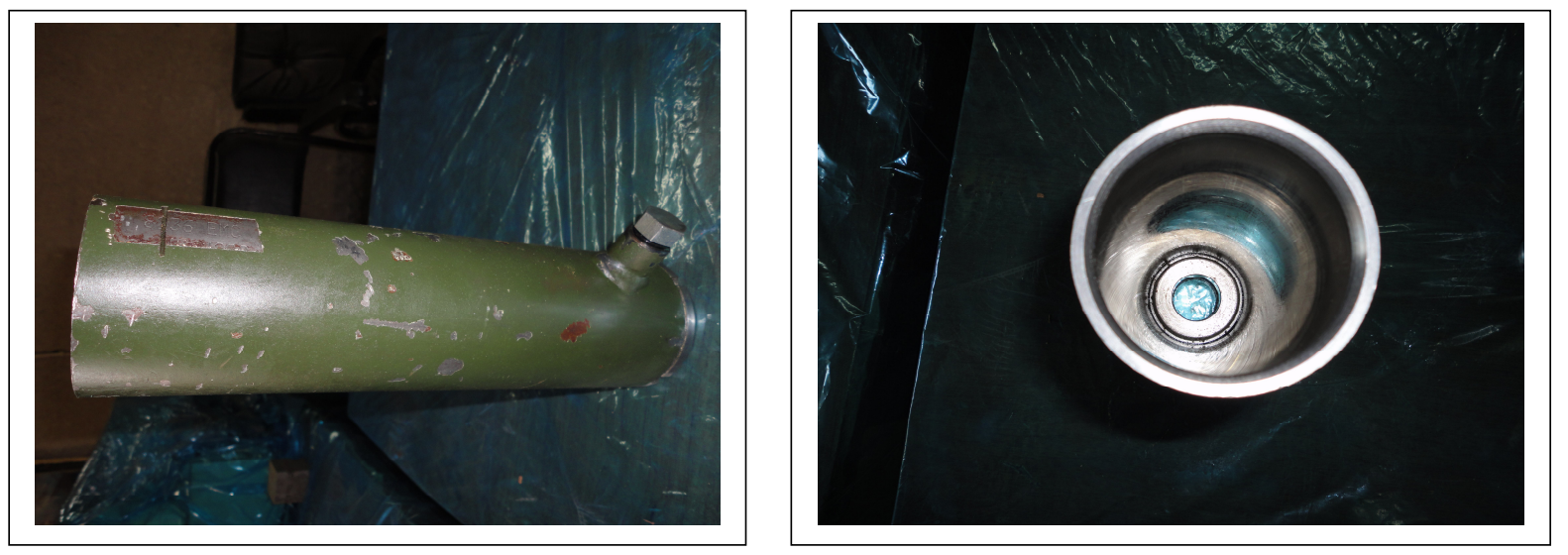

Fig.(4a): High-pressure extrusion container. Fig.(4b): High-pressure extrusion container.

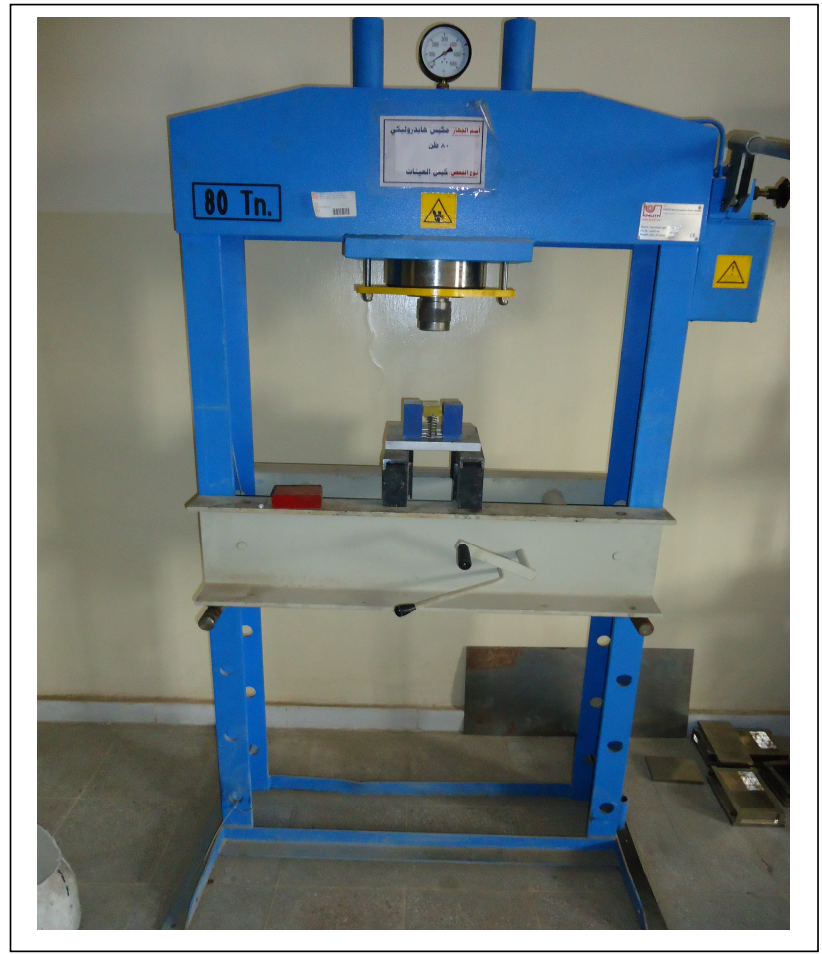

Fig.(5): High-pressure source (Press). 

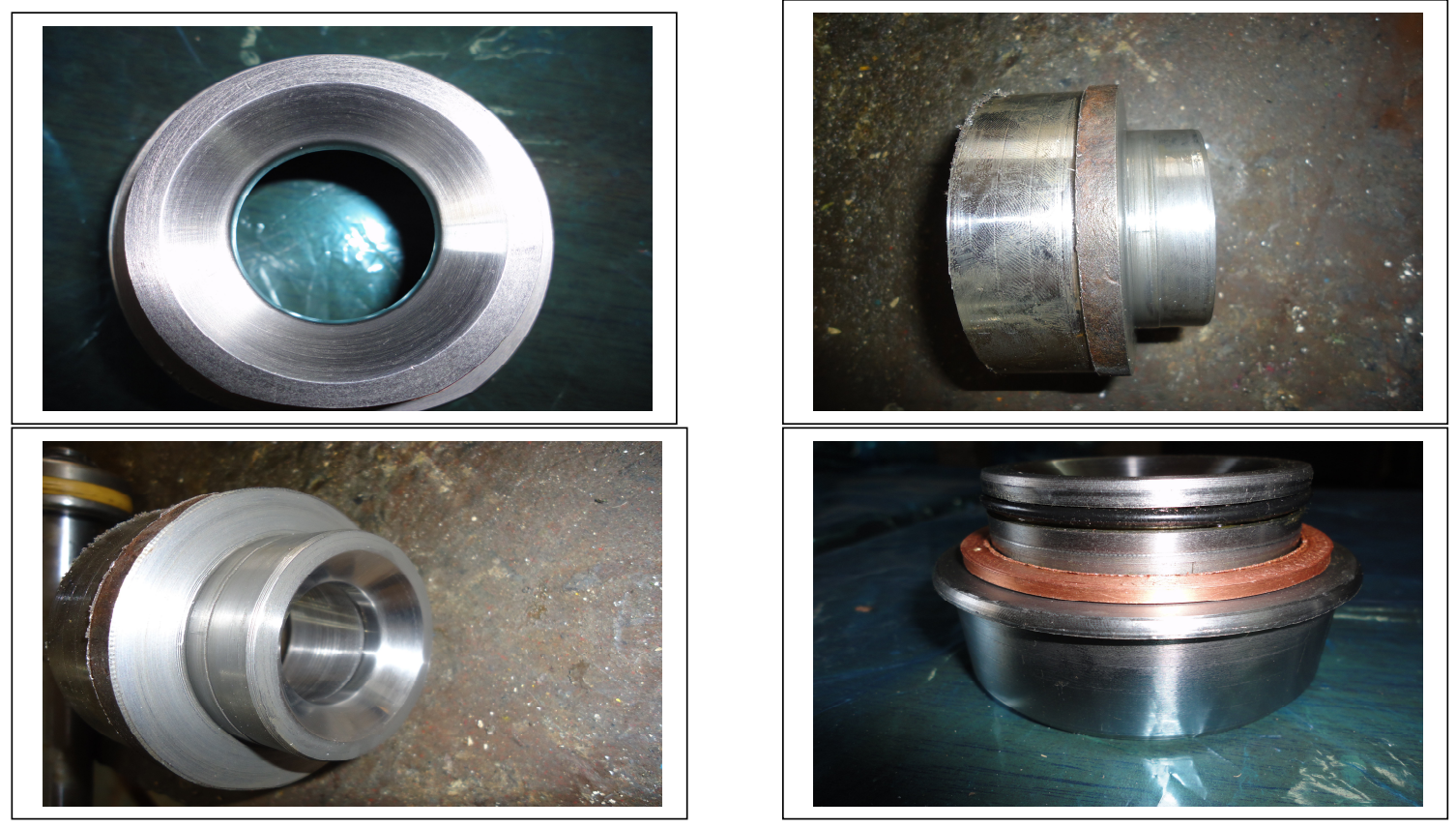

Fig.(6): Extrusion die.

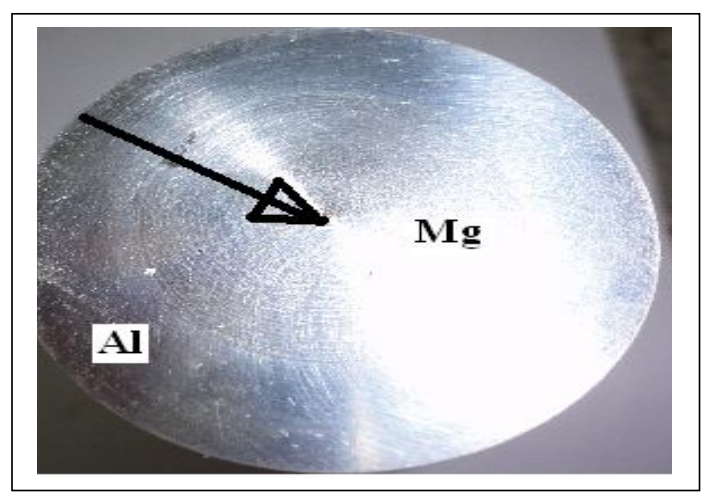

Fig.(7): The direct of measurement the Vickers hardness testing of compound cylinder(AL/Mg) from outside to center of sample.

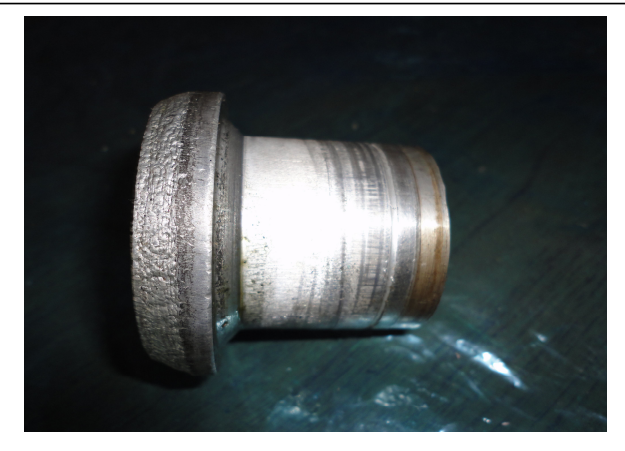

Fig.(9): Product from die $45 \mathrm{~mm}$

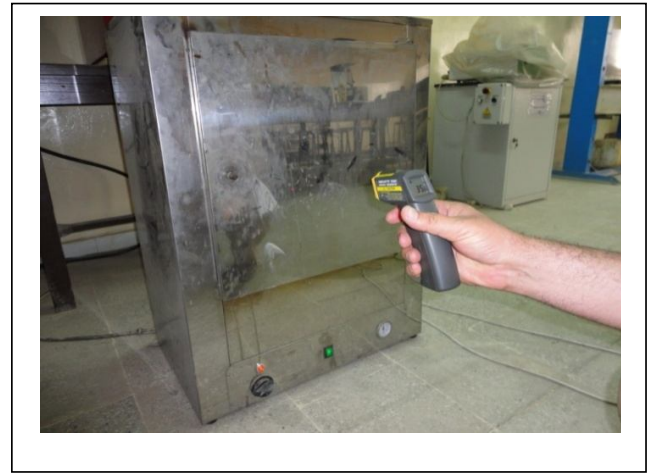

Fig.(8): System in furnace. 
DESIGN AND MANUFACTURING OF A HYDROSTATIC EXTRUSION APPARATUS FOR COMPOUND CYLINDERS FROM AL AND MG

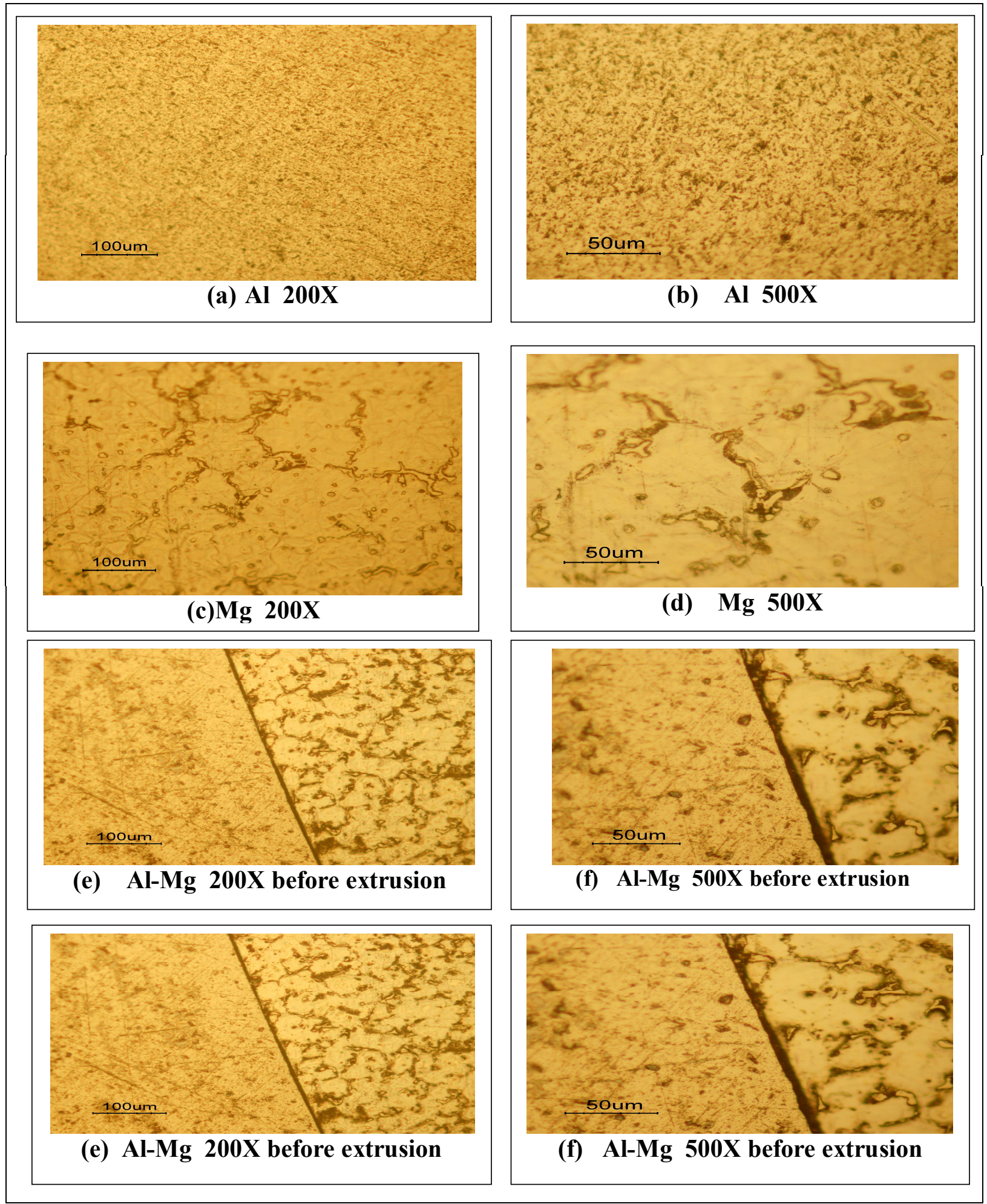

Fig.(10): Microstructure and grain size(a-n). 
DESIGN AND MANUFACTURING OF A HYDROSTATIC EXTRUSION APPARATUS FOR COMPOUND CYLINDERS FROM AL AND MG

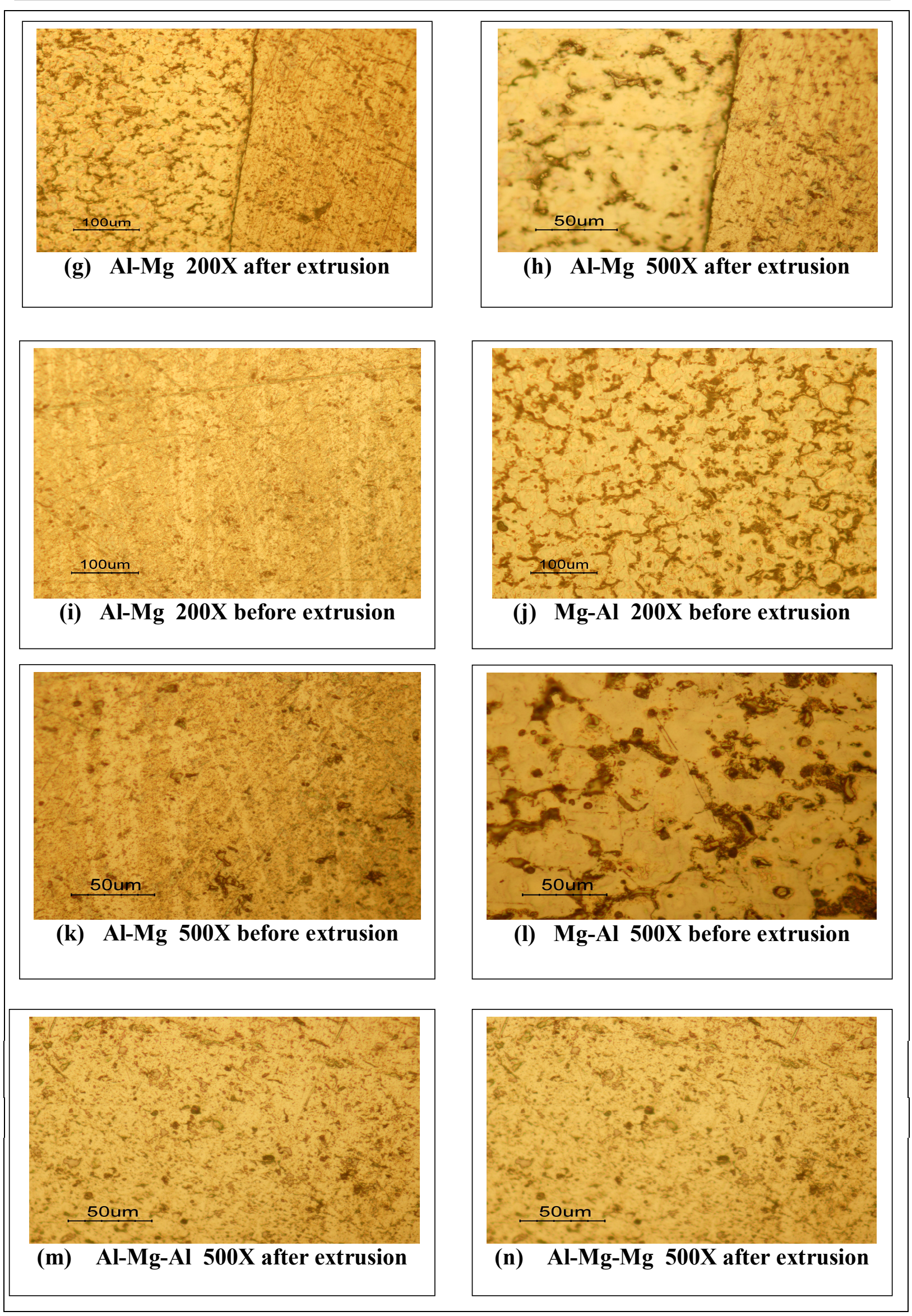

Fig.(10): Microstructure and grain size(a-n). 


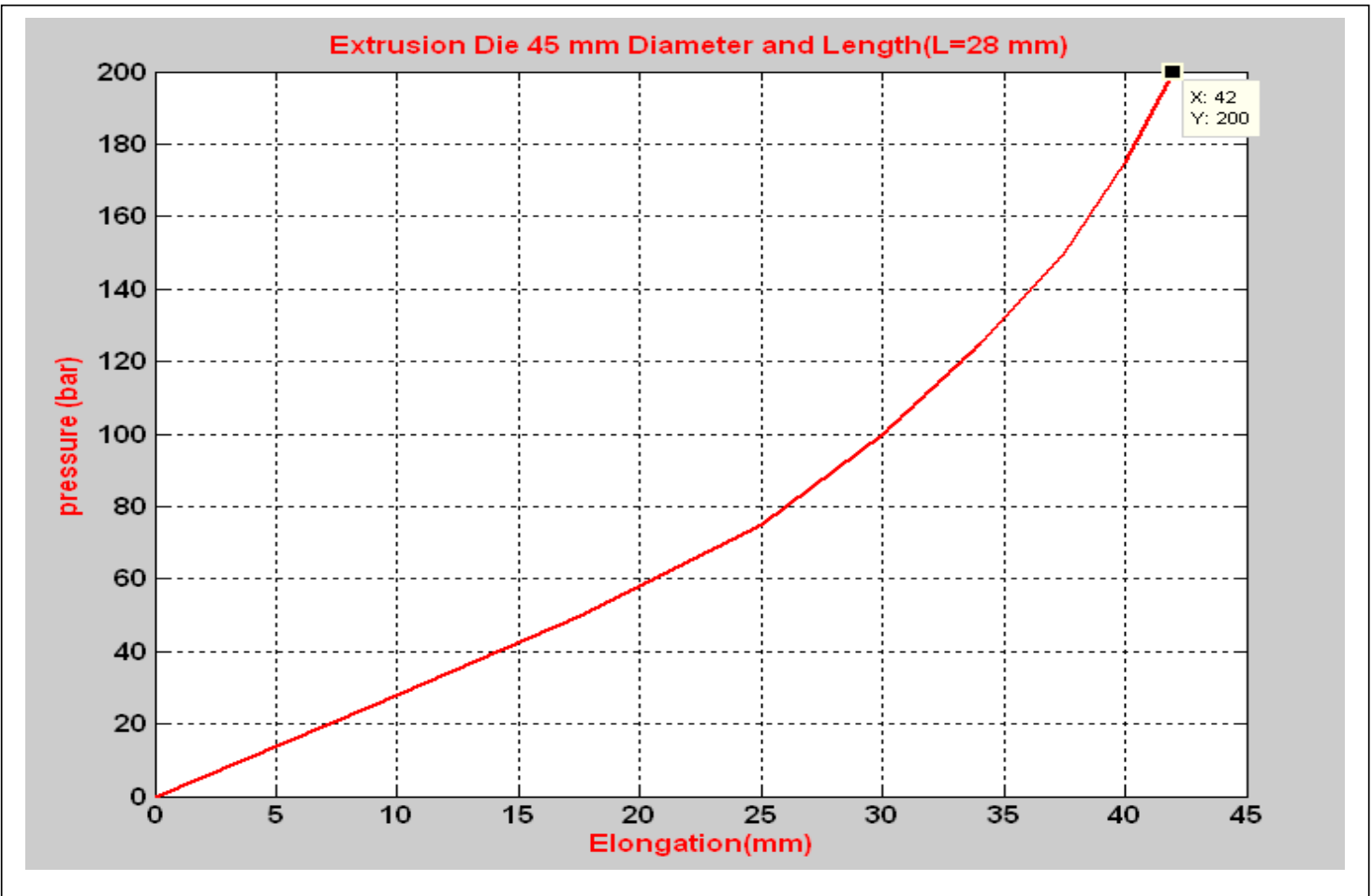

Fig.(11): Pressure versus elongation curve for Die 45,40,35 mm. 


\section{تصميم وتصنيع جهاز البثق الهايدروستاتيكي واطئ الكلقة للأسطوانة المركبة الألمنيوم}

\section{والمغتيسيوم}

عصام طارق عبد الله

مهندس

الكلية التقنية ـ بغداد
عبد الله ضايع عاصي

مدرس مساعد

معهد تكنولوجيا- بغداد

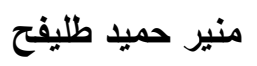

استاذ مساعد

الكلية التقنية - بغداد
محسن جبر جويج

استاذ

كلية الهندسة - جامعة

النهرين

\section{الخلاصة}

إن الغرض من هذا البحث هو تصميم وصنع وتجريب جهاز البثق الهايدروستاتيكي الذي يعمل في ضغط أعظم قيمة

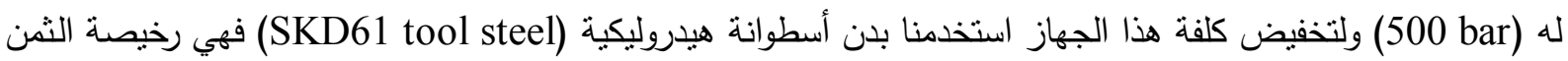

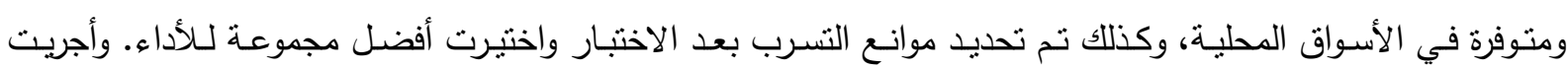
التجارب على عمليات البثق الهايدرستانيكي بعدة قوالب(45,40,35mm)، وتحليل النتائج أدى إلى زيادة التقة بهذا الجهاز وصولا إلى النتيجة النهائية التي تؤكد رصانة هذا الجهاز وعملية استخدامه ورخص كلفتهـ. 